\author{
А.В. Колесник ${ }^{1}$, С.В. Смеляков ${ }^{2}$, П.Г. Бердник ${ }^{3}$, О.І. Колодяжний ${ }^{2}$ \\ ${ }^{1}$ Льотна академія Наџіонального авіаційного університету, Кропивницький \\ ${ }^{2}$ Харківський національний університет Повітряних Сил ім. І. Кожедуба, Харків \\ ${ }^{3}$ Національний університет ім. В.Н. Каразіна, Харків
}

\title{
МЕТОД ОЦІНКИ РИЗИКУ ПРИ ВІДМОВІ ДВИГУНА НА ПОВІТРЯНОМУ СУДНІ В ПОЛЬОТІ НА ОСНОВІ МЕРЕЖІ БАЙЄСА
}

\begin{abstract}
Предметом вивчення в статmі є оиінка ризику для випадку виникнення особливої ситуації-відмові двигуна на повітряному судні в польоті. Метою є моделювання та кількісна оцінка ризику для випадку виникнення ситуацій, які можуть призвести до відмови двигуна на повітряному судні з використанням байєсівських мереж. Завдання: аналіз ряду математичних моделей, які дочільно використовувати для кількісної оцінки ризику в області безпеки польотів, побудова математичної моделі ризику, яка відображає розвиток можливих подій внаслідок відмови двигуна з використанням байєсівських мереж для визначення ймовірності виникнення авіаційних подій різного ступеня. Використовуваними методами є: теорія графів, байєсівські мережі, методи аналізу і синтезу складних інформаційних систем, методи імітаційно-статистичного моделювання. Отримані такі результати. Розроблений метод очінки ризику в сфері безпеки польотів, внаслідок реалізації такої небезпеки, як відмова двигуна на повітряному судні, заснований на застосуванні мереж Байєса. Побудована математична модель, щьо дозволяє визначити рівень ризику для випадку виникнення ситуацій, які можуть призвести до відмови двигуна в польоті у вигляді графа з таблииями безумовних, умовних та сумісних розподілів ймовірностей. За допомогою побудованої моделі визначено найбільш ймовірний наслідок прояву такої небезпеки як відмова двигуна на повітряному судні, а також найбільший рівень ризику. Висновки. Напрямком подальших досліджень є розробка та побудова системи підтримки прийняття рішень для удосконалення технологї роботи авіадиспетчера управління повітряним рухом
\end{abstract}

Ключові слова: ризик, авіаційні подї, мережа Байєса, відмова двигуна, особливі випадки в польоті.

\section{Вступ}

Постановка проблеми. Незважаючи на той факт, що авіаційний транспорт вважається одним 3 найбільш безпечним видом перевезень, проблема зменшення кількості авіаційних подій не втрачає своєї актуальності. Для виявлення істинних причин та їх попередження в майбутньому розслідування авіаційних подій здійснюють з точки зору впливу людського фактору, відмов авіаційної техніки, порушення правил виконання польотів, впливу умов зовнішнього середовища. Для забезпечення безпеки польотів необхідно вживати комплекс системних заходів, які потребують відповідного фінансування. У зв'язку з цим існує необхідність визначення першочергових ризиків авіаційних подій і відповідних заходів, які сприятимуть їх зниженню.

Особливі випадки в польоті представляють собою пряму загрозу безпеки польотів і зазвичай являються наслідком взаємодії декількох факторів. Небезпека таких ситуацій обумовлена неочікуваним характером їх виникнення і неможливістю завчасного прогнозування. Одним 3 можливих особливих випадків $\epsilon$ відмова двигуна(ів) на повітряному судні в польоті. Статистичний аналіз авіаційних подій показує, що відмова авіаційного двигуна займає значне місце серед інших причин авіаційних подій
(7,5\%). Отже актуальним є виявлення найбільш значних факторів небезпеки у випадку відмови двигуна 3 метою зниження аварійності і підвищення рівня безпеки польотів цивільної авіації.

Однією з варіантів оцінки ризику є визначення ризику у формі, наведеної в ICAO Doc 9859 [1], згідно якого рівень ризику виникнення авіаційних подій внаслідок впливу ситуацій, пов'язаних з відмовою двигуна можна оцінити на основі розрахунку ймовірності їх виникнення та ступеня серйозності.

Мета статті - оцінка ризику у випадку виникнення ситуацій, які можуть призвести до виникнення особливої ситуації - відмові двигуна(нів) на повітряному судні в польоті на основі мережі Байєса.

Аналіз останніх досліджень і публікацій. Питанням моделювання ризику в сфері безпеки польотів присвячено ряд робіт, наприклад [2-3]. Зокрема, в роботі [2] прогнозування ймовірності і виявлення факторів небезпеки здійснюється шляхом побудови “дерева небезпек” для випадку викочування за межі злітно-посадової смуги. В роботі [3] авторами проведено моделювання ризику для двох видів небезпек: помилок інженерно-технічного складу та помилок членів льотних екіпажів. Наявність такої кількості робіт свідчить про актуальність питань управління ризиками в сфері безпеки польотів. 


\section{Виклад основного матеріалу}

Будемо вважати, що в сфері безпеки польотів відбулася певна кількість несприятливих подій, що сталися 3 цивільними повітряними суднами (ПС) України, пов'язаних з відмовою двигуна. В якості несприятливих подій будемо мати на увазі авіаційні події та інциденти, отримані на основі звітів з безпеки польотів по результатам розслідування та узагальнення інформації щодо авіаційних подій та інцидентів, що сталися у період з 2017 по 2019 рік $з$ цивільними ПС (ПС, що внесені в Державний реєстр) [4-6] . Крім того, також будемо вважати, що мається перелік типів та причин відмов, що трапляються 3 двигуном(нами) на повітряному судні, а також очікуваних подій, внаслідок виникнення тієї чи іншої непередбачуваної ситуації, які отримані $з$ типових карт дій фахівців ОПР в аварійних та непередбачуваних ситуаціях (ASSIST) [7] та вищевказаних звітів з безпеки польотів.

Задача полягає у тому, щоб згідно даних щодо несприятливих подій, пов'язаних з відмовою двигуна і переліку типів та причин відмов, що трапляються 3 двигуном(нами) на повітряному судні, а також очікуваних подій, внаслідок виникнення тієї чи іншої непередбачуваної ситуації, побудувати математичну модель, що дозволить визначити ймовірність виникнення авіаційних подій різних рівнів серйозності.

Дана модель повинна враховувати різні групи факторів, що впливають на виникнення відмов двигуна на ПС (вплив навколишнього середовища, орнітологічна обстановка, відмови і несправності авіаційної техніки). В [8] для визначення рівня небезпеки пропонується п'ять можливих рівнів серйозності, наведені в табл. 1:

Таблиця 1

Шкала серйозності наслідків

\begin{tabular}{|c|c|c|}
\hline \multicolumn{2}{|c|}{ Шкала ІКАО } & \multirow[b]{2}{*}{ Авіаційні подія } \\
\hline $\begin{array}{c}\text { Серйозність } \\
\text { події } \\
\end{array}$ & Ступінь & \\
\hline катастрофічна & A & авіаційна катастрофа \\
\hline небезпечна & $\mathrm{B}$ & авіаційна подія \\
\hline значна & $\mathrm{C}$ & серйозний інцидент \\
\hline незначна & $\mathrm{D}$ & інцидент \\
\hline наднизька & E & $\begin{array}{c}\text { подія, що підлягає } \\
\text { розслідуванню }\end{array}$ \\
\hline
\end{tabular}

Згідно [1] під ризиком розуміють передбачувану ймовірність і важкість наслідків прояву одного чи декількох факторів небезпеки. В роботі [3] вказується на можливість математичної інтерпретації згідно підходу ІКАО за допомогою визначення ризику Каплана-Гаріка першого рівня. Стенлі Каплан і Б. Джон Гаррік (1981) визначають ризик як відповіді на три питання [8]:
1. Що може піти не так?

2. Наскільки ймовірно, що це піде не так?

3. Якщо це піде не так, то які наслідки?

Відповідно до цих відповідей ризик $R$ першого рівня представляється Капланом та Гарріком як набір наступних трійок:

$$
R=\left\{S_{i}, p_{i}, Y_{i}\right\},
$$

де $S_{i}$ - можливий сценарій розвитку несприятливої події; $p_{i}$ - ймовірність реалізації даного сценарію; $Y_{i}$ - наслідки реалізації даного сценарію (оцінка серйозності наслідків), $i=1 . . . N, N$ - кількість можливих сценаріїв.

Моделі та методи, що використовуються для оцінки ризику умовно поділяються на наступні групи [3]:

1) моделі ризику зіткнення (collision risk models);

2) моделі ризику відповідальності перед сторонніми особами (third-party risk model);

3) моделі помилок персоналу (human error models);

4) причинно-наслідкові або каузальні моделі (causal model).

Очевидно, що для вирішення вказаної задачі доцільним є застосування четвертої групи методів. Одним 3 можливих методів, що дозволяють здійснювати оцінку рівня безпеки польотів в умовах дії небезпечних факторів, ймовірність яких залежить від часу $є$ застосування ланцюгів Маркова. Також використовують методи ймовірнісного аналізу безпеки (FTA, ETA, FMEA) [9]. Загальним недоліком даних методів є застосування двійкової логіки (робочий або неробочий стан) при представленні елементів системи, яка розглядається. У зв'язку з цим вказані методи не є доцільними для використання при рішенні поставленої задачі. Даний недолік можливо усунути шляхом застосування мереж Байєса, які також входять до групи причинно-наслідкових методів оцінки ризику.

Математичний апарат мереж Байсса (МБ) дозволяє поєднати досить просте графічне представлення деякого процесу 3 його ймовірнісним характером, проаналізувати можливі варіанти розвитку ситуації, відслідкувати правильність встановлення причинно-наслідкового зв'язку між окремими подіями і завдяки цьому підвищити обгрунтованість рішень при аналізі складних проблемних ситуацій [10].

Мережа Байєса представляє собою графову ймовірнісну модель і формально, визначається як пара $\langle G, B\rangle$. Перша складова - $G$, це направлений ациклічний граф, що відповідає змінним процесу, що досліджується і будується у вигляді причиннонаслідкової мережі. Друга складова - $B$ множина 
параметрів, що визначають мережу. В мережі Байєса існує 2 види змінних. Змінну, що залежить від однієї або більшої кількості інших змінних називають нащзадком.

Змінну, що має одну або більше нащадків називають батьківською змінною. Одна і та сама змінна може бути батьківською для одних змінних і нащадком для інших. Якщо змінна не має батьків, то вона має назву коренева змінна, а якщо не має нащадків листок.

Для того, щоб визначити мережу Байєса необхідно задати розподіл маргінальних ймовірностей для кореневих змінних (вершин) і таблиці умовних ймовірностей для всіх інших.

Після цього виконується алгоритм первинної пропагації (розповсюдження) для отримання маргінальних ймовірностей вершин на основі апріорного виводу.

Основою байєсівського підходу є поняття умовної ймовірності $P(A \backslash B)=x$. Спільна ймовірність виникнення подій А і В визначається за формулою повної ймовірності:

$$
P(A, B)=P(A \backslash B) \cdot P(B)=P(B \backslash A) \cdot P(A) .
$$

Вираз (2) є фундаментальним правилом обчислення ймовірності і є основою теореми Байєса:

$$
P(B \backslash A)=\frac{P(A \backslash B) \cdot P(B)}{P(A)} .
$$

Якщо до експерименту ймовірності вершин були: $P\left(H_{1}\right), P\left(H_{2}\right) \ldots . . P\left(H_{n}\right)$ і після експерименту (появи свідоцтв) з'явилась подія А, то нові умовні ймовірності гіпотез розраховуються за формулою Байєса:

$$
P\left(H_{k} \backslash A\right)=\frac{P\left(A \backslash H_{k}\right) \cdot P\left(H_{k}\right)}{\sum_{i=1}^{n} P\left(H_{i}\right) P\left(A \backslash H_{i}\right)} .
$$

Далі розглянемо важливі поняття, що використовуються в мережах Байєса [10].

1. Маргіналізація - підсумовування ймовірностей усіх змінних мережі окрім обраних для обчислення ймовірностей змінних, які нас цікавлять на основі повної ймовірності.

2. Пропагація (розповсюдження) - процес обчислення апостеріорний ймовірностей для тих змінних мережі, які не спостерігаються на основі значень свідоцтв (спостережуваних вершин).

3. Логічний висновок - обчислення умовних ймовірностей деяких змінних на основі наданої інформації про інші змінні.

4. Ймовірність Байєса для деякої події $x$ - міра упевненості деякого експерта, що дана подія відбудеться.

5. Ланцюгове правило - це спосіб обчислення повної ймовірності у байєсівських мережах:

$$
\begin{aligned}
& P\left(X_{1}, X_{2} \ldots X_{n}\right)=P\left(X_{1}\right) \cdot P\left(X_{2} \backslash X_{1}\right) \cdot \\
& \cdot P\left(X_{3} \backslash X_{1}, X_{2}\right) \ldots \cdot P\left(X_{n} \backslash X_{1}, X_{2} \ldots X_{n-1}\right) .
\end{aligned}
$$

Проведемо моделювання ризику з використанням мереж Байєса. При збільшенні кількості вершин процес пропагації в мережі має експоненційний характер, отже у випадку складних мереж для автоматизації розрахунку доцільно користуватися програмними засобами моделювання мереж Байєса.

Широко розповсюдженим способом створення ймовірнісної моделі є задання чотирьох іiі складових, а саме: змінних моделі (вершин графа), залежностей між змінними, функціональних форм, що можуть приймати залежності та числові значення цих форм [11].

Найпростіший спосіб - це задати маргінальний розподіл ймовірностей (для кореневих змінних) i таблиці умовних ймовірностей для проміжних змінних і листків, що підходить лише для нескладних задач.

В даній роботі побудова графа буде здійснюватися на основі наступних принципів:

-кореневою вершиною графа $є$ події, що можуть призводять до відмови двигуна на повітряному судні, які визначені згідно [4-7];

-листком $є$ наслідки, які мають місце в результаті реалізації варіантів розвитку ситуації внаслідок відмови двигуна.

Далі визначимо змінні для кожної 3 вершин графа. Для кореневої вершини “Фактори небезпе$\kappa и$ ” застосовано 4 змінні з предикатами: “Зупинка двигуна", “Пожежа двигуна", "Нестійка робота двигуна”, “Потрапляння птахів".

Вершина-листок “Авіаційні подї” має чотири предикати згідно рівня серйозності наслідків, наведених у таблиці 1 від А до D.

Ступінь Е у даному випадку не застосовуємо, оскільки в аналізі авіаційних подій згідно [4-6], визначено випадки лише перших 4-х ступенів небезпеки.

Граф буде мати наступний вигляд (рис. 1).

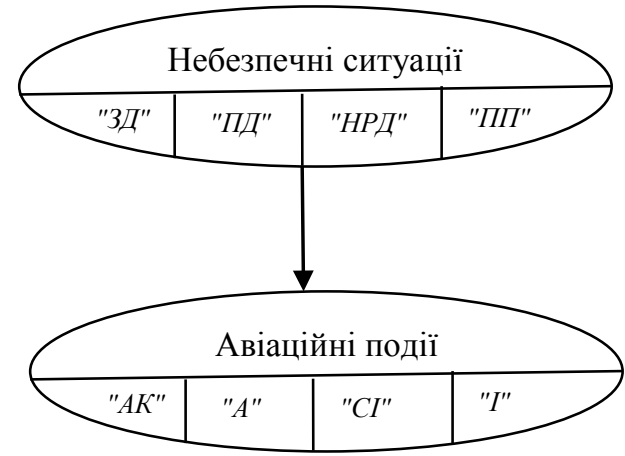

Рис. 1. Граф байєсівської мережі

Окрім ациклічного направленого графа необхідно задати маргінальні і умовні ймовірності його вершин. 
Вихідні дані, щодо кількості і причин виникнення авіаційних подій наведені в табл. 2 та 3.

Таблиця 2

Вихідні дані щодо ситуацій, пов'язаних з відмовою двигуна

\begin{tabular}{|l|c|}
\hline $\begin{array}{l}\text { Кількість годин нальоту з 2017 по } \\
2019 \text { рік }\end{array}$ & 900000 \\
\hline Загальна кількість авіаційних подій & 184 \\
\hline $\begin{array}{l}\text { Кількість подій, пов'язаних з відмовою } \\
\text { двигуна. 3 них: }\end{array}$ & 31 \\
\hline \multicolumn{1}{|c|}{ 1.Зупинка двигуна: } & 5 \\
\hline 2. Пожежа двигуна: & 2 \\
\hline 3. Нестійка робота двигуна & 15 \\
\hline \multicolumn{1}{|l}{ 4. Потрапляння птахів у двигун } & 10 \\
\hline
\end{tabular}

Таблиця 3

Вихідні дані щодо кількості авіаційних подій, пов'язаних з відмовою двигуна

\begin{tabular}{|c|c|c|c|c|}
\hline $\begin{array}{c}\text { Авіацій- } \\
\text { ні події }\end{array}$ & $\begin{array}{c}\text { Зупинка } \\
\text { дигуна" } \\
\text { жежа } \\
\text { двигу- } \\
\text { на” }\end{array}$ & $\begin{array}{c}\text { “Не- } \\
\text { стійка } \\
\text { робота } \\
\text { дигуна" }\end{array}$ & $\begin{array}{c}\text { Потрап- } \\
\text { ляння } \\
\text { птахів } \\
y \text { двигун }\end{array}$ \\
\hline Катастроф & 1 & - & - & - \\
\hline Аварій & 3 & - & 1 & 1 \\
\hline СІ & 1 & 1 & 1 & - \\
\hline I & - & 1 & 13 & 9 \\
\hline
\end{tabular}

Маргінальні ймовірності для кореневої вершини “Фактори небезпеки” розраховані згідно даних таблиці 2 та наведено далі (табл. 4).
Таблиця умовних ймовірностей $P(Y \backslash X)$ для вершини-листка “Авіаційні події, розрахована відповідно даних таблиці 3, наводиться в табл. 5.

Далі необхідно отримати сумісний розподіл ймовірностей, шляхом застосування ланцюгового правила до умовного розподілу ймовірностей.

Таблиця 4

Маргінальні ймовірності для кореневої вершини “Фактори небезпеки“

\begin{tabular}{|c|c|c|c|}
\hline \multicolumn{4}{|c|}{ Фактори небезпеки } \\
\hline $\begin{array}{l}\text { “Зупинка } \\
\text { двигуна” }\end{array}$ & $\begin{array}{l}\text { “Пожежа } \\
\text { двигуна" }\end{array}$ & $\begin{array}{l}\text { "Нестійка } \\
\text { робота } \\
\text { двигуна" }\end{array}$ & $\begin{array}{c}\text { “Потраплян- } \\
\text { ня птахів" }\end{array}$ \\
\hline 0,129 & 0,064 & 0,484 & 0,323 \\
\hline
\end{tabular}

Ланцюгове правило - це принцип, що застосовується до будь якої моделі залежності і при будь якій множині умовних розподілів ймовірностей змінних [11].

Для двох змінних $X$ та $Y$, де $P(X)$ - розподіл ймовірностей значень $X, P(Y \backslash X)$ - умовний розподіл $Y$ при умові $X$, згідно ланцюгового правила 3 двох розподілів отримуємо сумісний розподіл $X$ та $Y-P(X, Y)$.

Для будь яких можливих значень $x$ змінної $X$ та у змінної $Y$ ланцюгове правило визначається виразом:

$$
P(X=x, Y=y)=P(X=x) \cdot P(Y=y \backslash X=x) .
$$

Таблиця умовних ймовірностей для вершини-листка

“Авіаційні події”

\begin{tabular}{|c|c|c|c|c|}
\hline \multirow{2}{*}{$\begin{array}{c}\text { ФАКТОРИ } \\
\text { НЕБЕЗПЕКИ }\end{array}$} & \multicolumn{4}{|c|}{$\begin{array}{c}\text { АВІАЦІЙНІ } \\
\text { ПОДІЇ }\end{array}$} \\
\hline & Kamacmpoфа & Аварія & $\begin{array}{l}\text { Серйозний } \\
\text { інциидент }\end{array}$ & Інциидент \\
\hline “Зупинка двигуна" & 0,2 & 0,6 & 0,2 & 0 \\
\hline “Пожежа двигуна" & 0 & 0 & 0,5 & 0,5 \\
\hline "Нестійка робота двигуна" & 0 & 0,065 & 0,065 & 0,87 \\
\hline “Потрапляння птахів” & 0 & 0,1 & 0 & 0,9 \\
\hline
\end{tabular}

В скороченому вигляді вираз 5 має вигляд:

$$
P(X, Y)=P(X) \cdot P(Y \backslash X) \text {. }
$$

Ланцюгове правило узагальнюється для будь якої кількості змінних. Нехай існують змінні $X_{1}, X_{2} \ldots X_{n}$.

В стандартному формулюванні ланцюгового правила не робиться припущень щодо незалежності змінних, тобто вважається, що кожна змінна залежить від попередніх змінних.

Повне ланцюгове правило має наступний вигляд:

$$
\begin{aligned}
& P\left(X_{1}, X_{2} \ldots X_{n}\right)=P\left(X_{1}\right) \cdot P\left(X_{2} \backslash X_{1}\right) \cdot \\
& \cdot P\left(X_{3} \backslash X_{1}, X_{2}\right) \cdot \ldots P\left(X_{n} \backslash X_{1}, \ldots X_{n-1}\right)
\end{aligned}
$$

В табл. 6 наведено сумісний розподіл ймовірностей для вершин мережі Байєса, отриманий шляхом застосування ланцюгового правила.

Для розрахунку апріорних ймовірностей настання авіаційних подій різних рівнів серйозності необхідно застосувати правило повної ймовірності. 
Таблиця 6

Сумісний розподіл ймовірностей для вершин мережі Байєса

\begin{tabular}{|c|c|c|}
\hline $\begin{array}{c}\text { Фактори } \\
\text { небезпеки }\end{array}$ & Авіаційні події & Ймовірність \\
\hline "Зупинка двигуна" & Kатастрофа & 0,0258 \\
\hline "Зупинка двигуна" & Аварія & 0,0774 \\
\hline “Зупинка двигуна" & $\begin{array}{l}\text { Серйозний } \\
\text { інцидент }\end{array}$ & 0,0258 \\
\hline “Зупинка двигуна" & Іничидент & 0 \\
\hline $\begin{array}{l}\text { “Пожежа } \\
\text { двигуна" }\end{array}$ & Катастрофа & 0 \\
\hline $\begin{array}{l}\text { "Пожежа } \\
\text { двигуна" }\end{array}$ & Аварія & 0 \\
\hline $\begin{array}{l}\text { "Пожежа } \\
\text { двигуна" }\end{array}$ & $\begin{array}{l}\text { Серйозний } \\
\text { інцидент }\end{array}$ & 0,0320 \\
\hline $\begin{array}{l}\text { “Пожежа } \\
\text { двигуна" }\end{array}$ & Інциидент & 0,0320 \\
\hline $\begin{array}{c}\text { "Нестійка робота } \\
\text { двигуна" }\end{array}$ & Kатастрофа & 0 \\
\hline $\begin{array}{c}\text { "Нестійка робота } \\
\text { двигуна" }\end{array}$ & Аварія & 0,0315 \\
\hline $\begin{array}{c}\text { "Нестійка робота } \\
\text { двигуна" }\end{array}$ & $\begin{array}{l}\text { Серйозний } \\
\text { інцидент }\end{array}$ & 0,0315 \\
\hline $\begin{array}{c}\text { "Нестійка робота } \\
\text { двигуна" }\end{array}$ & Інциидент & 0,4210 \\
\hline $\begin{array}{c}\text { "Потрапляння } \\
\text { птахів" }\end{array}$ & Kaтастрофа & 0 \\
\hline $\begin{array}{c}\text { "Потрапляння } \\
\text { птахів" }\end{array}$ & Аварія & 0,0323 \\
\hline $\begin{array}{c}\text { "Потрапляння } \\
\text { птахів" }\end{array}$ & $\begin{array}{l}\text { Серйозний } \\
\text { інциидент }\end{array}$ & 0 \\
\hline $\begin{array}{c}\text { "Потрапляння } \\
\text { птахів" }\end{array}$ & Інщицдент & 0,2907 \\
\hline
\end{tabular}

Позначимо $X_{1}, X_{2} \ldots X_{n}-$ змінні, чий сумісний розподіл нас цікавить, а $Y_{1}, Y_{2} \ldots Y_{m}$ - змінні, по яким проводиться операція додавання. Позначимо $Z_{1}, Z_{2} \ldots Z_{l}$ - змінні, які фігурують в умові.

Правило повної ймовірності стверджує, що для будь яких значень $x_{1}, \ldots x_{n}$ змінних $X_{1}, \ldots X_{n}$ та значень $Z_{1}, Z_{2} \ldots Z_{l}$ змінних $Z_{1}, Z_{2} \ldots Z_{l}$ :

$$
\begin{gathered}
P\left(X_{1}=x_{1}, . . X_{n}=x_{n} \backslash Z_{1}=z_{1}, \ldots Z_{l}=z_{l}\right)= \\
\sum_{y_{1}} . \sum_{y_{m}} P\left(X_{1}=x_{1}, . . X_{n}=x_{n}, Y_{1}=y_{1}, . . Y_{m}=y_{m} \backslash Z_{1}=z_{1}, . . Z_{l}=z_{l}\right) .
\end{gathered}
$$

Даний вираз означає, що для розрахунку умовної ймовірності того, що змінні $X_{1}, X_{2} \ldots X_{n}$ приймають значення $X_{1}, \ldots X_{n}$, необхідно виконати додавання ймовірностей тих елементів, повного умовного розподілу всіх змінних, для яких ці змінні приймають вказані значення. В скороченій нотації вираз (8) буде мати вигляд:

$$
P\left(X_{1}, . . X_{n} \backslash Z_{1}, \ldots Z_{l}\right)=\sum_{y_{1}} \cdot \sum_{y_{m}} P\left(X_{1}, . . X_{n}, Y_{1}, \ldots Y_{m} \backslash Z_{1}, . . Z_{l}\right)
$$

Розраховані маргінальні ймовірності настання авіаційних подій наведені в табл. 7.

Таблиця 7

Апріорні ймовірності настання авіаційних подій

\begin{tabular}{|c|c|c|c|}
\hline \multicolumn{4}{|c|}{ АВІАЦІЙНІ } \\
ПОДІї \\
\hline Катастрофа & Аварія & $\begin{array}{l}\text { Серйозний } \\
\text { інцџидент }\end{array}$ & Інцииент \\
\hline 0,0258 & 0,1412 & 0,0893 & 0,7437 \\
\hline
\end{tabular}

В документі [1] визначено матрицю ризиків ICAO, яка має наступний вигляд (табл. 8):

\begin{tabular}{|c|c|c|c|c|c|c|}
\hline \multirow{2}{*}{\multicolumn{2}{|c|}{$\begin{array}{l}\text { Ймовірність } \\
\text { ризику }\end{array}$}} & \multicolumn{5}{|c|}{ Серйозність ризику } \\
\hline & & $\begin{array}{c}\text { Катастрофічна } \\
\text { А }\end{array}$ & $\begin{array}{c}\text { Небезпечна } \\
\text { В }\end{array}$ & $\begin{array}{c}\text { Значна } \\
\text { C }\end{array}$ & $\begin{array}{c}\text { Незначна } \\
\text { D }\end{array}$ & $\begin{array}{c}\text { Дуже незначна } \\
\text { Е }\end{array}$ \\
\hline Часто & 5 & $5 \mathrm{~A}$ & $5 \mathrm{~B}$ & $5 \mathrm{C}$ & $5 \mathrm{D}$ & $5 \mathrm{E}$ \\
\hline Іноді & 4 & $4 \mathrm{~A}$ & 4B & $4 \mathrm{C}$ & $4 \mathrm{D}$ & $4 \mathrm{E}$ \\
\hline Рідко & 3 & $3 \mathrm{~A}$ & 3B & $3 \mathrm{C}$ & $3 \mathrm{D}$ & $3 \mathrm{E}$ \\
\hline Малоймовірно & 2 & $2 \mathrm{~A}$ & $2 \mathrm{~B}$ & $2 \mathrm{C}$ & 2D & $2 \mathrm{E}$ \\
\hline Дуже малоймовірно & 1 & $1 \mathrm{~A}$ & 1B & $1 \mathrm{C}$ & 1D & $1 \mathrm{E}$ \\
\hline
\end{tabular}

Таблиця 8

Матриця ризиків ICAO

В роботі [3] наводиться модифікована шкала ймовірностей, що дозволяє співставити кожній можливості певний діапазон значень (табл. 9):

Таблиця 9

Шкала ймовірностей

\begin{tabular}{|l|l|c|}
\hline \multicolumn{2}{|c|}{ Ймовірність виникненя } & Інтервал \\
\hline Часто & 5 & $(0,1 ; 1]$ \\
\hline Іноді & 4 & $(0,01 ; 0,1]$ \\
\hline Рідко & 3 & $(0,001 ; 0,01]$ \\
\hline Малоймовірно & 2 & $(0,0001 ; 0,001]$ \\
\hline Дуже малоймовірно & 1 & $(0 ; 0,0001]$ \\
\hline
\end{tabular}

Проведемо визначення рівня ризику виникнення авіаційних подій внаслідок впливу ситуацій, пов'язаних з відмовою двигуна згідно наведених вище класифікацій (табл. 10).

Таблиця 10

Рівень ризику виникнення авіаційних подій

\begin{tabular}{|c|c|c|}
\hline \multirow{2}{*}{ Серйозність } & \multicolumn{2}{|c|}{$\begin{array}{c}\text { Висновок для вершини } \\
\text { “Авіаційні подіï” }\end{array}$} \\
\cline { 2 - 3 } & Ймовірність & $\begin{array}{c}\text { Рівень } \\
\text { ризику }\end{array}$ \\
\hline Катастрофічна & 0.0258 & $4 \mathrm{~A}$ \\
\hline
\end{tabular}


Закінчення табл. 10

\begin{tabular}{|l|l|l|}
\hline Небезпечна & 0,1412 & 5B \\
\hline Значна & 0,0893 & $4 \mathrm{C}$ \\
\hline Незначна & 0,7437 & $5 \mathrm{D}$ \\
\hline
\end{tabular}

Згідно отриманих результатів можливо зробити висновок, що найбільш ймовірними наслідками прояву такої небезпеки як відмова двигуна на повітряному судні $\epsilon$ інцидент, а найбільшому рівню ризику відповідає рівень ризику 5D.

Таким чином в роботі вирішено дві задачі, а саме: визначення ймовірності виникнення різних несприятливих подій у випадку виникнення небезпечних ситуацій, пов'язаних $з$ відмовою двигуна i визначення рівня ризику для такої особливої ситуації в польоті.

Сутність методу оцінки ризику у випадку виникнення небезпечних ситуацій, пов'язаних з відмовою двигуна полягає у представлені моделі ризику у вигляді графа мережі Байєса. Коренева вершина графа відображає небезпечні ситуації, що можуть призвести до відмови двигуна в польоті, ймовірності виникнення яких визначено згідно статистичних даних звітів 3 безпеки польотів. Вершина листок відображає наслідки реалізації цих небезпек (авіаційні події), класифікація яких визначена документом ICAO Doc 9859. Розрахунок ймовірностей ви- никнення авіаційних подій виконано за допомогою правила повної ймовірності. Рівень серйозності ризику визначено згідно шкали ICAO.

\section{Висновки}

Розроблено метод оцінки ризику в сфері безпеки польотів, внаслідок реалізації такої небезпеки, як відмова двигуна на повітряному судні, заснований на застосуванні мереж Байєса. Побудована математична модель ризику, що відображає розвиток можливих наслідків при виникненні ситуацій, які можуть призвести до особливої ситуації в польоті відмові двигуна(нів) на повітряному судні.

Показана можливість практичного застосування мереж Байєса для визначення ймовірності виникнення авіаційних подій різних рівнів серйозності із застосуванням таблиць безумовних, умовних ймовірностей та сумісного розподілу ймовірностей.

Проведено розрахунок ймовірностей виникнення наслідків прояву вказаної небезпеки, а також визначено найбільш ймовірний наслідок та рівень ризику.

Напрямком подальших досліджень є розробка та побудова системи підтримки прийняття рішень для удосконалення технології роботи авіадиспетчера управління повітряним рухом.

\section{Список літератури}

1. ICAO Doc 9859 AN/474 Safety Management Manual (SMM). Third edition. - Montréal: International civil aviation organization, 2013. - $254 \mathrm{p}$.

2. Макаров В.П. Разработка в авиакомпании системы менеджмента рисков в отношении безопасности полетов / В.П. Макаров // Труды Московского авиационного института. - 2014. - № 68. - С.1-15.

3. Рухлинский В.М. Оценка риска в области безопасности полетов на основе байесовской сети доверия / В.М. Рухлинский, А.А. Хаустов, А.С. Молотовник / Научный Вестник МГТУ ГА. - 2017. - № 20(3). - С. 76-88.

4. Офіційний сайт GOV.UA. Аналіз стану безпеки польотів за результатами розслідування авіаційних подій та інцидентів з цивільними повітряними суднами України та суднами іноземної реєстрації, що сталися у 1 півріччі 2019 року. - Режим доступу: http://www.nbaai.gov.ua/uploads/pdf/_2019.pdf.

5. Офіційний сайт GOV.UA. Аналіз стану безпеки польотів за результатами розслідування авіаційних подій та інцидентів з цивільними повітряними суднами України та суднами іноземної реєстрації, що сталися у 2018 році. - Режим доступу: http://www.nbaai.gov.ua/uploads/pdf/Analysis2018.pdf.

6. Офіційний сайт GOV.UA. Аналіз стану безпеки польотів за результатами розслідування авіаційних подій та інцидентів 3 цивільними повітряними суднами України та суднами іноземної реєстрації, що сталися у 1 півріччі 2017 році. - Режим доступу http://www.nbaai.gov.ua/uploads/pdf/Analysis_2017.pdf.

7. Положення про організацію роботи об'єктів обслуговування повітряного руху Украероруху: наказ Украероруху від 12.03.2008 № 64 (з поправками №1-№10). - К.: Украерорух, 2008. - 52 с.

8. Kaplan S. On the Quantitative Definition of Risk / S. Kaplan, B. Garrick // Risk Analysis. - 1981. - № 1. - P. 11-27.

9. Шаров В.Д. Методология применения комбинированного метода FMEA-FTA для анализа риска авиационного события / В.Д. Шаров, В.П. Макаров // Научный вестник МГТУ ГА. - 2011. - № 174. - С. 19-25.

10. Байєсівські мережі в системах підтримки прийняття рішень / М.3. Згуровський, П.І. Бідюк, О.М. Терентьєв, Т.І. Просянкіна-Жарова. - Київ: Едельвейс, 2015. - 300с.

11. Пфеффер А. Вероятностное программирование на практике / А. Пфеффер; Пер. с англ. А.А. Слинкин. - М.: ДМК Прес, 2017. - 46 с.

12. Зубков Б.В. Теория и практика определения рисков в авиапредприятиях при разработке системы управления безопасностью полетов / Б.В. Зубков, В.Д. Шаров. - М.: МГТУ ГА, 2010. - 196с.

\section{References}

1. International civil aviation organization (2013), ICAO Doc 9859 AN/474 Safety Management Manual (SMM). Third edition, Montréal, $254 \mathrm{p}$

2. Makarov, V.P. (2014), "Razrabotka v aviakompanii sistemy menedzhmenta riskov v otnoshenii bezopasnosti poletov" [Development of an airline risk management system in relation to flight safety], Proceedings of the Moscow Aviation Institute, 
No. 68 , pp. $1-15$

3. Ruhlinskij, V.M., Haustov, A.A. and Molotovnik, A.T. (2017), “Otsenka riska v oblasti bezopasnosti poletov na osnove bajesovskoj seti doverija" [A shade of risk in the field of flight safety based on the Bayesian network of trust], Scientific Bulletin of Moscow State Technical University of Civil Aviation, No. 20(3), pp.76-88.

4. The official site of GOV.UA (2019), “Analiz stanu bezpeki pol'otiv za rezul'tatami rozsliduvannja aviatsijnih podij ta intsidentiv z tsivil'nimi povitrjanimi sudnami ukraïni ta sudnami inozemnoï reestratsï̈, scho stalisja u 1 pivrichchi 2019 roku” [Analysis of the state of flight safety based on the results of the investigation of aviation accidents and incidents with civil aircraft of Ukraine and vessels of foreign registration, which occurred in the 1st half of 2019], available at: www.nbaai.gov.ua/uploads/pdf/_2019.pdf.

5. The official site of GOV.UA (2018), “Analiz stanu bezpeki pol'otiv za rezul'tatami rozsliduvannja aviatsijnih podij ta intsidentiv z tsivil'nimi povitrjanimi sudnami ukrä̈ni ta sudnami inozemnoï reestratsï̈, scho stalisja u 1 pivrichchi 2018 roku” [Analysis of the state of flight safety based on the results of the investigation of aviation accidents and incidents with civil aircraft of Ukraine and vessels of foreign registration, which occurred in the 1st half of 2018], available at: www.nbaai.gov.ua/uploads/pdf/Analysis2018.pdf.

6. The official site of GOV.UA (2017), “Analiz stanu bezpeki pol'otiv za rezul'tatami rozsliduvannja aviatsijnih podij ta intsidentiv z tsivil'nimi povitrjanimi sudnami ukraïni ta sudnami inozemnoï reestratsiï, scho stalisja u 1 pivrichchi 2017 roku" [Analysis of the state of flight safety based on the results of the investigation of aviation accidents and incidents with civil aircraft of Ukraine and vessels of foreign registration, which occurred in the 1st half of 2017], available at: www.nbaai.gov.ua/uploads/pdf/Analysis2017.pdf.

7. Order of Ukraeroruh (2008), "Polozhennja pro organizatsiju roboti ob'ektiv obslugovuvannja povitrjanogo ruhu Ukraeroruhu vid 12.03.2008 No. 64" [Regulations on the organization of work of Ukraeroruh dated 12.03.2008 No. 64], 52 p.

8. Kaplan, S. and Garrick, B. (1981), On the Quantitative Definition of Risk, Risk Analysis, No. 1, pp. 11-27.

9. Sharov, V.D. and Makarov, V.P. (2011), "Metodologija primenenija kombinirovannogo metoda FMEA-FTA dlja analiza riska aviatsionnogo sobytija” [Methodology of application of the combined FMEA-FTA method for risk analysis of an aviation event], Scientific Bulletin of Moscow State Technical University of Civil Aviation, No. 174, pp. 19-25.

10. Zgurovs'kij, M.Z., Bidjuk, P.I., Terentyev, O.M. and Prosjankina-Zharova, T.I (2015), "Bajesivs'ki merezhi v sistemah pidtrimki prijnjattja rishen" [Bayesian networks in decision support systems], $300 \mathrm{p}$.

11. Pfeffer, A. (2017), "Verojatnostnoe programmirovanie na praktike" [Probabilistic programming in practice], DMK Pres, Moscow, $462 \mathrm{p}$.

12. Zubkov, B.V. and Sharov, V.D. (2010), "Teorija i praktika opredelenija riskov v aviapredprijatijah pri razrabotke sistemy upravlenija bezopasnost'ju poletov" [Theory and practice of risk identification in airlines in the development of safety management system], MGTU GA, Moscow, 196 p.

Надійшла до редколегії 27.02.2020

Схвалена до друку 10.03.2020

\section{Відомості про авторів:}

\section{Колесник Анна Василівна}

інспектор навчального відділу

Льотної академії

Національного авіаційного університету,

Кропивницький, Україна

https://orcid.org/0000-0003-3089-815X

\section{Смеляков Сергій В'ячеславович}

доктор фізико-математичних наук професор професор кафедри

Харківського національного університету

Повітряних Сил ім. I. Кожедуба,

Харків,Україна

https://orcid.org/0000-0002-5791-2479

\section{Берднік Поліна Григорівна}

кандидат технічних наук доцент кафедри Національного університету ім. В.Н. Каразіна, Харків, Україна

https://orcid.org/0000-0002-4022-5664

\section{Колодяжний Олександр Іванович}

кандидат технічних наук

доцент кафедри

Харківського національного університету

Повітряних Сил ім. І. Кожедуба,

Харків, Україна

https://orcid.org/0000-0001-9406-4248

\section{Information about the authors:}

\author{
Anna Kolesnyk \\ Inspector of Education Department \\ of the National Aviation University \\ "Flight Academy of the National Aviation University", \\ Kropyvnytskyi, Ukraine \\ https://orcid.org/0000-0003-3089-815X
}

\section{Serhii Smelyakov}

Doctor of Physics and Mathematics Professor

Professor of Department

of Ivan Kozhedub Kharkiv

National Air Force University,

Kharkiv, Ukraine

https://orcid.org/0000-0002-5791-2479

\section{Polina Berdnik}

Candidate of Technical Sciences

Senior Lecturer of Department

of Karazin Kharkiv National University,

Kharkiv, Ukraine

https://orcid.org/0000-0002-4022-5664

\author{
Oleksandr Kolodyazyy \\ Candidate of Technical Sciences \\ Senior Lecturer of the Department \\ of Ivan Kozhedub Kharkiv \\ National Air Force University, \\ Kharkiv, Ukraine \\ https://orcid.org/0000-0001-9406-4248
}




\section{МЕТОД ОЦЕНКИ РИСКА ПРИ ОТКАЗЕ ДВИГАТЕЛЯ НА ВОЗДУШНОМ СУДНЕ В ПОЛЕТЕ НА ОСНОВЕ СЕТЕЙ БАЙЕСА}

А.В. Колесник, С.В. Смеляков, П.Г. Бердник, А.И. Колодяжный

Предметом изучения в статье является оценка риска для случая возникновения особой ситуации-отказе двигателя на воздушном судне в полете. Целью является моделирование и количественная оценка риска для случая возникновения ситуаций, которые могут привести к отказу двигателя на воздушном судне с использованием байесовских сетей. Задачи: анализ ряда математических моделей, которые целесообразно использовать для количественной оценки риска в области безопасности полетов, построение математической модели риска, которая отражает развитие возможных событий в результате отказа двигателя с использованием байесовских сетей для определения вероятности возникновения авиационных происшествий разной степени. Используемыми методами являются: теория графов, байесовские сети, методы анализа и синтеза сложных информационных систем, методы имитационно-статистического моделирования. Получены следуюшие результаты. Разработан метод оценки риска в области безопасности полетов, 6 результате реализации такой опасности, как отказ двигателя на воздушном судне, основанный на применении сетей Байеса. Построена математическая модель, позволяющая определить уровень риска для случая возникновения ситуаичии, которые могут привести к отказу двигателя в полете в виде графа с таблицами безусловных, условных и совместных распределений вероятностей. С помощью построенной модели определены наиболее вероятный результат проявления такой опасности как отказ двигателя на воздушном судне, а также наибольший уровень риска. Выводы. Направлением дальнейших исследований является разработка и построение системы поддержки принятия решений для совершенствования технологии работы авиадиспетчера управления воздушным движением

Ключевые слова: риск, авиационные события, сеть Байеса, отказ двигателя, особые случаи в полете.

\section{METHOD FOR ASSESSING THE RISK OF ENGINE FAILURE IN AN AIRCRAFT IN FLIGHT USING BAYESIAN NETWORKS}

A. Kolesnyk, S. Smelyakov, P. Berdnyk, O. Kolodyazyy

The subject of the study in the article is the risk assessment for the case of a special situation-engine failure on the aircraft in flight. The goal is to model and quantify the risk in the event of situations that could lead to engine failure on an aircraft using Bayesian networks. The tasks are: analysis of a number of mathematical models that should be used to quantify safety in the field of safety, construction of a mathematical model of risk, which demonstrates the development of possible events as a result of engine failure using Bayesian networks. This is necessary to determine the probability of aviation accidents of varying degrees. The methods used are: graph theory, Bayesian networks, methods of analysis and synthesis of complex information systems, methods of simulation and statistical modeling. The following results were obtained. A mathematical model is built, which allows to determine the level of risk in the event of such a danger as engine failure on the aircraft. A mathematical model is built, which allows to determine the level of risk in the event of such a danger as engine failure on the aircraft. The table is made using Bayesian networks, has the form of a graph with tables of unconditional, conditional and joint probability distributions. A mathematical model is built, which allows to determine the level of risk in the event of such a danger as engine failure on the aircraft. The table is made using Bayesian networks, has the form of a graph with tables of unconditional, conditional and joint probability distributions. With the help of the constructed model the most probable result of manifestation of such danger as failure of the engine on the aircraft is defined. The highest level of risk is also determined. Conclusions. The direction of further research is development and construction of a decision support system to improve the operation of the air traffic controller.

Keywords: risk, aviation events, Bayesian network, engine failure, special cases in flight. 